\title{
Business games in teaching foreign students professional Russian language
}

\author{
Irina Kondratieva ${ }^{1,{ }^{*}}, \quad$ Nadezhda Malina ${ }^{1}$, Tatiana Rogacheva ${ }^{1}$, and Elena \\ Vyshegorodskaya $^{1}$ \\ ${ }^{1}$ Don State Technical University, 1, Gagarina square, 344003, Rostov-on-Don, Russia
}

\begin{abstract}
The article analyzes the use of business games that simulate real situations when teaching Russian to foreign students in order to form the required professional competencies. Simulation games are considered as an important element that contributes to increasing the motivation of learning, activating the process of communication in a non-native language and making decisions in the professional sphere. The authors pay special attention to the consideration of approaches to solving the problems of advanced training of engineering students. It is noted that the business game, which simulates various aspects of the professional environment and real production processes, allows you to train students to apply the theoretical knowledge gained and solve problems that arise in their professional activities. The advantages of using business games over traditional learning technologies are considered: free communication, an captivating and exciting game process contribute to the development of communication skills of students who have the language barrier in other conditions of language learning. It is noted that the business game allows you to form linguistic competencies in conditions close to real ones, promotes the development of creative thinking, and the acquisition of teamwork skills in the professional sphere.
\end{abstract}

\section{Introduction}

Integration of Russia into the world educational space requires the training of specialists with knowledge that meets international standards. The knowledge acquired by foreign students in the universities of the Russian Federation should enable future engineers to quickly adapt to the requirements dictated by the current economic and social transformations. Therefore, in addition to deep fundamental knowledge, good professional training in the field of special disciplines, the ability to apply the acquired knowledge in practice is required. Business games are becoming an important component of learning that simulates real situations. Learning games are very fun, motivate learners to take concrete actions, stimulate communication and offer many benefits as an additional learning tool.

Researchers note that business games are a means of encouraging intrinsic motivation in learning, facilitate its perception, and contribute to the development of general professional skills [1]. New approaches in methodology and pedagogy to the development of business games are determined, first of all, by the need to train future specialists in making

\footnotetext{
*Corresponding author: Irina-kondratieva@yandex.ru
} 
professional decisions. When preparing games for managers, for example, a modeling tool is used that allows you to experiment with a scenario of joint decision-making, taking into account market requirements and strategic decisions in the supply chain, etc. [2].

Scientists investigate imitation games in education and marketing, consider the possibility of objectively assessing the results of business games, and explain the reasons for failures in assessing students' work during the game. The need to create clear assessment criteria during the development and preparation of the game and to familiarize students with these criteria is emphasized [3]. The specificity and assessment of the assessment mechanism of educational games is related to the integration of educational analytics and the provision of a tool for creating assessments. However, the development of an educational game and criteria for its assessment is very difficult, mainly due to its interdisciplinary aspect [4].

The opinions of teachers refer to the use of commercial digital (computer) games and video games, e-learning and multimedia technologies in the learning process $[5,6,7,8,9]$. The possibility of using a multiplayer online game MMOG is noted. The researchers are analyzing the experiences of using this content in English and Business courses that used an MMOG-based curriculum [10].

A lot of attention is paid all over the world to the use of imitation role-playing games in teaching foreign languages. Teachers of the Peoples' Friendship University of Russia note the urgent need to introduce intercultural components into communication skills when teaching foreign languages at the university. This study aimed to clarify the effectiveness of role play and business stimulants in the acquisition of intercultural knowledge, skills and attitudes [11].

Educators from China are exploring play as the basis for the formation of creativity in teaching English as a foreign language in China [12]. Scientists from different countries analyze the regional educational experience in the field of early learning of foreign languages [13], determine the importance of play as an integral part of language learning, give a description of games, their classification and advantages for teaching English to children [14].

When describing business games, much attention is paid to the experience of teamwork, cooperation, interaction, the ability to complete a task, the solution of which depends on the ability to negotiate between group members $[15,16,17]$. The skills acquired by students when playing business stimulants are analyzed [18].

Business games play an important role in teaching engineering students. The article discusses approaches to solving the problems of advanced training of students of engineering specialties. To form professional competencies and motivation for learning, it is proposed to use a business game as an active teaching method, which is an effective tool for preparing students for future professional activities. The business game as a tool for modeling various aspects of the professional environment and real production processes allows to teach students to apply the obtained theoretical knowledge and solve problems that arise in their professional activities [19].

\section{Main part}

Currently, the universities of the Russian Federation use various forms of enhancing the educational process, effectively affecting the result of the educational process. Among them can be emphasized a play method aimed at preparing a future specialist for professional activity.

The game form is created in the classroom with the help of game techniques and situations that act as a means of motivating, stimulating students to educational activities. The implementation of game techniques and situations is carried out on the basis of the 
introduction of the rules of the game and the element of competition, when a didactic goal is transformed into a game goal and the execution of a didactic task is associated with a game result. Gaming technologies are increasingly used in teaching Russian to a foreign audience. Free communication, fun and exciting game process contribute to the development of communication skills of students who have the language barrier in other conditions of language work. It should be noted that game language technologies are designed to form students' pronunciation, lexical and grammatical skills and train the use of language constructions at the stage of mastering the Russian language.

The educational business game is a practical lesson that simulates various aspects of the professional activity of future specialists and demonstrates the complex use of their knowledge of the subject of professional activity and the degree of proficiency in Russian as a means of professional communication.

The business game has such an important feature for the development of speech as modeling in the game the conditions of professional activity close to real ones, i.e. this is the simulation of the very professional activity of future engineers in the design, production and maintenance of equipment. The action in the business game takes place in one of the spheres of the trainees 'professional activity, therefore, modeling the conditions of the students' professional activity in the business game is mandatory. A business game presupposes the obligatory joint activity of the game participants performing the roles provided for by the conditions of the game with a pre-developed system for evaluating the course and results of the game and controlling the playing time.

Business games contribute to the intensive development of skills in the use of a foreign language, primarily in listening, dialogic and monologue speech, the rational assimilation of foreign language knowledge, especially by focusing the attention of students on especially important aspects of knowledge. In the business game, independent work predominates, the mental activity of students is activated and the activity increases, since the role behavior of the participants is a factor in the intensification of the educational process. Students have a feeling of satisfaction from joint actions, there is a desire to solve engineering problems. The business game develops the skills of establishing contact in Russian, developing communication tactics using the speech capabilities of the Russian language.

Unlike traditional practical classes, active forms and methods of teaching allow you to bring the educational process closer to reality, imitating professional activities. In other words, the role of the business game as one of the methods in teaching professionaloriented communication of foreign students in Russian at a technical university should be called quite significant, which, of course, intensifies the educational process, allows to a certain extent to solve educational problems, overcome psychological and linguo-cultural barriers. Moreover, business game forms the communicative competence of the future specialist. A business game forms teamwork skills, which is a professionally significant quality of a specialist's personality. The influence of a business game on the activation of the educational process and on the level of motivation of teaching Russian language to foreign students can be recognized as undeniable, since the use of this particular methodology, to a greater extent than in traditional classes, creates the communicative competence of students.

One of the aspects of professional training of a specialist is the achievement of foreign language communicative competence, which is characterized by the level of formation of speech skills and abilities in relation to professionally significant situations, which ensures adequate speech and business behavior. In the process of business communication, there are not enough skills in the grammatical speech field, it is necessary to know the characteristics of the country of the target language, the mentality of its people. 
In the business game, not only the intellectual capabilities of the student and his memory are used, but also the expression of various intentions - agreement, disagreement, interest, clarification; various states of a person - surprise, displeasure, excitement and others. All this can be done in Russian by students who have a good command of the first and second certification levels. Students play these emotional states using a certain intonation, facial expressions, gestures, choosing the appropriate speech tactics. In this case, motivation plays an important role, i.e. an internal lever that directs the activities of the participants in the game to solve any problems. Motivation is influenced by the relevance of the content of the game, the collective interaction of trainees, the imitation of the environment of future professional interaction. From a psychological point of view, it is necessary to create a positive attitude in the learning process, including a means of increasing motivation can be the relationship between the teacher and students, which affects the organization of the exchange of opinions between the participants in the game, when attention is paid to the professionally significant qualities and personality characteristics of the participants in the game: initiative, politeness, attentive attitude to the interlocutor, benevolence, the ability to compromise, and at the same time - adherence to principles.

Scientists note the leading place of play in the social formation of a person as a subject of cognition and activity. In artificially recreated conditions, a person plays different life and work situations, which is necessary for his development, changing his social positions, roles in society, for the formation of professional interests, needs and skills. Business games are a relatively new phenomenon in education, at least in a mass form of application. The most important task is not only the ability to select the necessary knowledge, systematize it, but also the ability to transform this knowledge, bring it closer to life and professional situations, to the practice of professional activity. This is seen as the main goal of using business games as one of the most effective teaching methods.

Conducting business games is a collective method of learning, therefore, as a result of the game, participants learn to come up with a joint solution in accordance with the overall goals of the team. One of the main sources of the effectiveness of business games is saving time in mastering certain language structures; in a short time, students develop skills that cannot be obtained with other teaching methods. The effectiveness of training is manifested in the interested attitude of the participants to the training business game. This psychological factor activates trainees, which contributes to a more intensive assimilation and memorization of the necessary educational information related to the professional training of specialists. Based on the results of assessing the activities of participants during business games, it is possible to get a fairly complete picture of the professional and personal qualities of the participants, their readiness to solve practical problems, to lead activities.

Business games serve as a didactic tool for the development of creative (theoretical and practical) professional thinking, including the ability to analyze the production situation, formulate and solve new problems, substantiate the chosen solutions; they simulate production processes and professional activities of specialists. Business games are the main way of involving partners in joint activities and at the same time - a way of creating and resolving problematic gaming situations through communication. The rules of the game reflect the characteristics of real processes and phenomena that take place in the prototypes of the simulated reality. The goals of business games can be extremely diverse, but the main thing is to clearly define them in the process of developing a game scenario.

Achievement of goals occurs through the sequential adoption of individual, and then group decisions, therefore, in preparation, it is necessary to formulate rules and clarify the step-by-step sequence of decision-making (Table 1). 
Table 1. Requirements for the organization and conduct of the game.

\begin{tabular}{|l|l|}
\hline \multicolumn{2}{|c|}{ Requirements for the organization and conduct of the game } \\
\hline 1. & $\begin{array}{l}\text { The presence of pre-prepared questions for discussing the process of the game and its } \\
\text { results. }\end{array}$ \\
\hline 2. & Implementation of constant feedback between game participants. \\
\hline 3. & $\begin{array}{l}\text { Adaptation to the corresponding contingent of students, their level of language } \\
\text { proficiency. }\end{array}$ \\
\hline 4. & $\begin{array}{l}\text { Involvement of specialists from different directions performing different functions in the } \\
\text { game (support team, consultants, group leaders, and others). }\end{array}$ \\
\hline 5. & Creation of a workable team from scattered specialists capable of solving the task. \\
\hline 6. & $\begin{array}{l}\text { Development of motivation for the participants in the game (interest, curiosity of the } \\
\text { participants, the possibility of having alternative opinions). }\end{array}$ \\
\hline 7. & $\begin{array}{l}\text { Taking into account the psychological characteristics of the personality of students to } \\
\text { regulate the level of emotional and intellectual tension during the game. }\end{array}$ \\
\hline
\end{tabular}

Questions prepared in advance for discussing the results and the process of the game do not exclude the spontaneity of actions and speech behavior of the participants and the moderator at this stage. Participants receive mutual feedback, share their experiences, note positive and, possibly, negative moments during the game. Sometimes there is a need or desire to improve and continue the game. For the successful conduct of a business game, adaptation to the appropriate contingent of students, their level of language proficiency is necessary, which is important if we evaluate this type of work as a form of improving the training of future specialists.

To conduct the game, it is advisable to involve specialists from different directions who perform certain functions in the game (support group, consultants, group leaders, and others). The organizational task of the leader is to coordinate the collective activities of the participants in the game, their personal and intergroup communication at all stages of the consideration of the problem. To mobilize the participants, it is advisable to involve them in the discussion. The task of this stage is to create a workable team from scattered specialists capable of solving the task. After the end of the game, it is appropriate to discuss the course of the game together with the participants, to listen to their opinions, suggestions and wishes on the methodology of the game, as well as on the relationship of the participants. It should be noted that the playful form of work is not so common in the educational process of the university or in the activities of the work collective, therefore there are grounds for motivation - this is the interest, curiosity of the participants, the possibility of having alternative opinions. Social and psychological characteristics of students' personality are also important in the business game to regulate the level of emotional and intellectual tension in the classroom.

The need to control the game should not lead to unnecessary interference by the moderator in the course of the game, especially to his authoritarianism. Such a position of the leader blocks the game behavior of the participants, reduces the efficiency of reflection and openness in expressing feelings during the discussion of the results and the entire process of the game.

To correct and improve the process of designing business games, it is useful and sometimes necessary to conduct research work, which is determined, as a rule, by the following parameters: the psychological climate in the group, the intellectual activity and productivity of the participants, the degree of initiative and the real contribution of each participant, the distribution of game roles. A business game can be considered not only a means of teaching, but also a means of forming professional skills, with the help of which communicative skills can be transformed into professional and communicative ones. This is a tool that contributes to improving the effectiveness of vocational education by the method 
of imitating decision-making in various situations, which is an intermediate link between the theory and practice of teaching.

A business game in Russian language classes with foreign students can be used as a teaching method and a method of control. For the successful organization and conduct of a business game, it is necessary to match the game with the goals and objectives of training, the level of speech training. In the classroom, preparation can be carried out for a business game using traditional dialogue and polylogue, work on lexical and grammatical material in language exercises for substitution, transformation, word formation, etc. Playing micro situations in dialogues, you can control the degree of assimilation of the material. At the same time, attention must be paid to the linguistic design of phrases that are gradually becoming more complex in content and structure. Students must be able to realize their speech intentions, and in a business game they clearly understand this, paying attention not only to speech behavior, but also to demeanor, gestures, tempo and timbre of speech, business style of clothing, etc. Students positively evaluate the game method of inclusion into language as an effective way of teaching professionally oriented communication in a foreign language. The level of motivation is growing not only due to interest in the topic, but this is also facilitated by the fact that psychological and creative potential is revealed. The priority task of teaching Russian as a foreign language at a technical university is teaching professionally oriented communication. The communication process is complex and multifaceted; it integrates the information component and the empathy of the participants.

In the classroom on Russian as a foreign language at the Don Technical University (DSTU) with the students of the Agroindustrial Faculty, the imitation role-playing game is used as a teaching method that allows solving speech-meaningful learning problems, motivating students' actions, carrying out problematic organization of educational material, using authentic material and communicating valuable phrases, that is, those that are used in communication, and not just correct in terms of language. The game introduces constant novelty and heuristic, when voluntary memorization and reproduction of memorized are excluded, when a constant variability of all exercises, materials and conditions is provided.

Traditional situational and role-based learning has received a new understanding at the present stage. The principle of communication requires a rethinking of some familiar concepts. A situation should be understood not as a set of extralinguistic circumstances, but as a system of interrelationships between interlocutors, reflected in their minds; under situational - the correlation of the statement with these relationships. The situation is not a segment of reality, but speech activity itself, therefore, such basic features of activity as content, a certain structure, etc. are inherent in it. Speech units used in speech situations are presented as a recording of speech actions in natural situations, acting out of speech situations by informants, an associative experiment. Learning goals, situational field (breadth of context) determine the set of material for each situation, the depth of its discussion. Speech situations in various spheres of communication are heterogeneous in their structure: in the social sphere they are monothematic, in the social and cultural sphere they are polythematic.

The organization of material for teaching communication should be situationalthematic, that is, it should represent a number of situations related to various areas of communication, as well as a certain linguistic level of grammatical structure, speech patterns, words, expressions, colloquial formulas, etc. Such a situational-thematic principle of organizing the communicative content of teaching oral speech is based on such factors as the clarity factor of the goal, the regulatory factor, the communication factor, the game factor.

In the educational process, various modifications of games are used: positional (involves clarifying the position through a struggle of opinions); imitative-role (events, 
human activities are imitated, positions and roles are determined in advance); plot (positions and roles are reflected, but the plot remains the leading one); situational (have intense action in a relatively short time); organizational and activity (develop theoretical concepts and practical recommendations, design various types of activities); organizational and creative (developing a concept for a new type of activity) (Table 2).

Table 2. Modifications of games in the educational process.

\begin{tabular}{|l|l|l|l|l|l|}
\hline \multicolumn{7}{|c|}{ Modifications of games in the educational process } \\
\hline Positional & $\begin{array}{l}\text { Imitation- } \\
\text { role based }\end{array}$ & Subjective & Situational & $\begin{array}{l}\text { Organizational } \\
\text { and activity }\end{array}$ & $\begin{array}{l}\text { Organizationa } \\
\text { and } \\
\text { creative }\end{array}$ \\
\hline $\begin{array}{l}\text { It involves } \\
\text { clarifying } \\
\text { the position } \\
\text { through the } \\
\text { struggle of } \\
\text { opinions. }\end{array}$ & $\begin{array}{l}\text { Events, } \\
\text { activities of } \\
\text { people are } \\
\text { imitated, } \\
\text { positions } \\
\text { and roles are } \\
\text { predetermin } \\
\text { ed. }\end{array}$ & $\begin{array}{l}\text { Positions } \\
\text { and roles } \\
\text { are } \\
\text { displayed, } \\
\text { but the } \\
\text { plot } \\
\text { remains } \\
\text { the lead. }\end{array}$ & $\begin{array}{l}\text { They have } \\
\text { an intense } \\
\text { effect in a } \\
\text { relatively } \\
\text { short time. }\end{array}$ & $\begin{array}{l}\text { They develop } \\
\text { theoretical } \\
\text { concepts and } \\
\text { practical } \\
\text { recommendations, } \\
\text { carry out the } \\
\text { design of various } \\
\text { types of activities. }\end{array}$ & $\begin{array}{l}\text { The concept } \\
\text { of a new typ } \\
\text { of activity is } \\
\text { beingdevelopd } \\
\text {. }\end{array}$ \\
\hline
\end{tabular}

Role-playing games are widely used in the learning process, but many forms require careful preparation. A game is a type of activity in situations aimed at recreating and assimilating social experience and understanding the mentality of the country of the target language, in which not only language proficiency is formed and improved, but also understanding of the opponent's train of thought, self-control of behavior. The concept of the game is disclosed in a prospectus that reflects its general content and conditions of use, i.e. it indicates the theme and goals of the game, the models of the participants' activities. The situation becomes a component of an imitation role-playing game.

In the scenario the characteristics of the object of the game are given, the roles are established and substantiated, the rules of the game are determined. The game environment reflects the fundamental decisions on the form of interaction between the players during the game (with the help of game items, using documents, preparing presentation materials). For each game, the rules are established, which indicate the order of playing, the time order of the game. To conduct the game, an administrator is appointed who heads the group of game organizers. Then the game teams are formed and the roles are distributed among the players. To resolve possible conflict situations and misunderstandings, as well as to help the players, a group of experts is created.

The principles of building a game include the following: clarity and simplicity of the design (model) of the simulation role-playing game; completeness of themes and fragments of the game; the possibility of further improvement and development of structures (models) of the role-playing game; use of off-the-shelf developments, software products; clarity of all elements in solving the problem studied in the game.

The principles of the game are the full immersion of the participants in the imitationrole-playing game in the problems of the organizational system modeled in the game; gradual entry of participants into the experimental situation; uniform load; the plausibility of the experimental situation; participation of the teacher.

The simulation-business game ensures the interest of the participants, increases the motivation for learning. The educational goals of the game include the stimulation of students' speech activity in monologic and dialogical forms; mobilization and development of means of speech expression; consolidation of skills of abstracting, public speaking and discussion. Professional goals include using language skills, speech skills, and professional 
knowledge to solve a problem. The educational goals include the formation of students' skills of work in a team, the upbringing of a creative perception of the environment among students of a technical university (Table 3).

Table 3. Goals of the business game.

\begin{tabular}{|l|l|}
\hline \multirow{4}{*}{ Learning goal } & 1.Stimulation of students' speech activity in monologic and dialogical forms. \\
\cline { 2 - 3 } 2. Mobilization and development of means of speech expression. \\
\cline { 2 - 3 } Professional goal & $\begin{array}{l}\text { 3. Strengthening the skills of abstracting, public speaking and conducting } \\
\text { discussion. }\end{array}$ \\
\hline \multirow{2}{*}{ Educational purpose } & $\begin{array}{l}\text { Using language skills, speech skills and professional knowledge to solve the } \\
\text { problem. }\end{array}$ \\
\cline { 2 - 3 } & $\begin{array}{l}\text { 1. Formation of students' teamwork skills. } \\
\text { 2. Fostering a creative perception of the environment among students of a } \\
\text { technical university. }\end{array}$ \\
\hline
\end{tabular}

When preparing the game, a plan is developed that defines the stages of the game.

At the first stage, there is an introduction to the problem, preparation of the content side of the game, the topic is determined, the main means of speech interaction.

At the second stage, the type of event is determined (meeting, conference, exhibition of achievements, exhibition and sale of equipment).

At the third stage, a script is drawn up, roles are carefully written, and the direction of the discussion is determined.

The fourth stage is the holding of the game event itself.

The fifth stage is expert assessment. If the game is connected with the competition, the winners of the game are determined (Table 4).

Table 4. Stages of the game.

\begin{tabular}{|c|c|c|c|c|}
\hline \multicolumn{5}{|c|}{ Stages of the game } \\
\hline Stage I & Stage II & Stage III & Stage IV & Stage V \\
\hline $\begin{array}{l}\text { Introduction to } \\
\text { the problem, } \\
\text { definition of the } \\
\text { content side of } \\
\text { the game, } \\
\text { definition of the } \\
\text { topic. }\end{array}$ & $\begin{array}{l}\text { Determination of } \\
\text { the type of event } \\
\text { (round table, } \\
\text { conference, } \\
\text { briefing, etc.). }\end{array}$ & $\begin{array}{l}\text { Writing a script, } \\
\text { assigning roles, } \\
\text { determining the } \\
\text { direction of the } \\
\text { discussion. }\end{array}$ & $\begin{array}{l}\text { Conducting the } \\
\text { event-game itself. }\end{array}$ & $\begin{array}{l}\text { Expert } \\
\text { assessment. }\end{array}$ \\
\hline
\end{tabular}

In the first year, foreign students study and discuss topics: "The scientist and his role in the life of society", "The qualities of a scientist", "Nobel laureates". In accordance with the section of the textbook "Nobel Prizes and Nobel Laureates", students are offered the game "Press Conference": students are correspondents of various newspapers and magazines, they have the opportunity to interview a scientist who was familiar with A.D. Sakharov, inventor of the hydrogen bomb and Nobel Peace Prize laureate. One of the students, playing the role of a scientist, studies the life of the hero, uses information from various sources, prepares to answer questions. The rest of the students prepare questions. The teacher - the presenter (moderator) of the press conference - warns in advance that the conference time is limited, so you can only ask two or three questions. In Russian language classes, students read texts dedicated to the Nobel Prize and Nobel laureates, get acquainted with the biography of A.D. Sakharov, study expressions used in interviews:

At the beginning of the interview:

- Allow me to introduce myself, a correspondent of the newspaper "Vesti Dona".

- I would like to ask you a few questions.

- May I ask you a few questions?

- Could you answer a number of questions?

- I have a few questions for you. 


\section{During the interview:}

- Could you answer this question ...

- The next question will be like this ...

- It's interesting to know what you think about ...

- Don't you think that ...

- And the last question ...

\section{At the end of the interview:}

- Thank you. It was interesting to meet you and hear your story.

- Thank you for the interesting interview. I think it was interesting for our readers to meet you. Until next time.

- Thank you very much for the interview. Let me wish you great success in your work and new interesting discoveries.

Depending on the interests of students and the material being studied, the interviewee may be the engineer, inventor, or designer himself. From technical means, you can use a video camera, a dictaphone for recording performances and further analysis.

To study and consolidate the topic: "Man and the environment", an imitation roleplaying game "The impact of scientific and technological progress on the environment" was developed. The game is recommended for second-year students, as students have the required level of proficiency in Russian and professional knowledge. In accordance with the chosen situation, the roles of students are determined: ecologist, engineer, press secretary, space exploration specialist, energy scientist, representatives of different countries - forum participants, businessman, correspondents [20, 21].

To successfully master the terminology of the specialty and increase the active vocabulary of the future engineer, during preparation for a business game, students study agrotechnical vocabulary, analyze stylistic differences in types of speech, perform lexical and grammatical exercises, gain public speaking skills, and prepare presentations to defend their project.

Students of the Agro-industrial Faculty participate in business games that reproduce various industrial situations. During the preparation for the game-meeting on the problems of weed control, students study the names of weeds in Russian, agrotechnical methods of combating them. If this is a fertilizer application technology, the terminology of the fertilizer application technique is studied: direct flow, reloading, transshipment. Students get acquainted with the advantages of domestic equipment (loader-excavator, loaderhopper, seeder-cultivator, grain-press seeder, dotted corn seeder, subsoiler-fertilizer, cultivator-plant feeder, spreader of mineral fertilizers, sprayer) and foreign machines (loader bags of fertilizers, seeder universal precision seeding) for fertilization, give their technical characteristics, analyze possible shortcomings.

In a business game that invites students to become plow sales managers, each person on the team represents a particular brand of plow and proves its advantages in working with different soils and in different climates and weather conditions. The game also features a service team and experts assessing student achievement.

In any industry, in any sphere, objective phenomena and their signs are correlated, interrelated, systematically organized into the concepts of a given industry, into its terminological system. Terminology is the basis of a professional apparatus that plays an important role in the training of a specialist. In the process of preparing a business game, when working with terminology, the teacher of Russian as a foreign language pays attention to the creation of complex word-terms, the use of prefixes in verbs of movement converted into nouns.

A detailed acquaintance of the student with the situation is important, since only in this case it is possible to defend his point of view, convince the interlocutor and make the 
correct individual or team decision. Foreign students are offered speech constructions for expressing agreement, disagreement, incomplete or partial consent.

To express consent:

- I fully share this point of view;

- I am of the same opinion;

- One cannot but agree with this;

- Certainly (undoubtedly) it is;

- This is beyond doubt;

- I subscribe to this opinion;

- Everything said is absolutely true.

To express disagreement:

- I do not share this opinion (this point of view);

- I have a different opinion;

- It's hard to agree with these;

- I have great doubts about it;

- I look at this question differently;

- From my point of view, this is far from the case;

- It seems to me that the situation is different;

- Let me disagree with you.

To express incomplete or partial consent:

- To some extent this is correct, but still ...;

- This is not entirely correct, from my point of view ...;

- I'm not entirely sure that this is so;

- Basically it is correct, though ...;

- Let's admit that this is correct, but ...;

- Of course, one can agree with this, however....

When teaching the Russian language, it becomes possible to use a variety of methods and technologies, which makes it possible to make classes interesting, to achieve the greatest effect in solving the task [22]. A distinctive feature of pedagogically oriented business games is that along with participation in interpersonal communication in the social sphere, the functions of professional activity are also realized.

\section{Conclusion}

Proceeding from the more particular principle of communicative modeling of a pedagogical situation, a business game, being an imitation method, is characterized by an approximation to real activity. The trainees are given the opportunity to get a general idea of the features of a particular process, which cannot be done in the usual mode of work in the classroom. As a result, the cognition of the learning process also grows, characterized by the fact that students receive and assimilate more information based on examples from real life, concrete reality, which contributes to the acquisition of decision-making skills by the game participants in professional situations.

The motivation created in this case provides a certain emotional mood of the players in the group. The attitude of the trainees to those situations that were the subject of the business game, and also to the players who served as characters in the business game, changes significantly. A favorable moral and psychological atmosphere motivates students for interpersonal interaction, the manifestation of mutual interest and creative initiative throughout the entire period of the business game.

A business game is also a collective teaching method, where there is an element of discussion and collective decisions are made. The result of collective activity depends on 
the performance of specific roles by the participants in the game in conditional communication situations.

The activity of students in the process of a business game is manifested so clearly that it is not episodic, but continuous. The very atmosphere of the business game makes the participants be active. The self-assessments of the learners change, they become more objective, and, in addition, in a number of cases, depending on the content and nature of the game, the assessments of their own capabilities change, since in the game it is possible to transfer the participant of the game to the world of "virtual reality", in which there is an opportunity to freely experimenting creatively without fear of mistakes.

Business games, as a method of active learning, help to increase efficiency in the theoretical and practical aspects of training future specialists, they allow you to simulate various production situations, to design ways of action in the conditions of the proposed models. The use of models of real socio-economic systems in business games makes it possible to bring the learning process as close as possible to the real conditions of practical activity of managers and specialists. Making management decisions in business games is carried out by participants performing certain roles, and since interests in this case do not always coincide, the decision has to be made in conflict situations. And, consequently, the participants have to look for and find constructive forms of resolving contradictions, which is rather difficult in speech behavior for foreign students.

Thus, the business game has many reserve opportunities to revitalize students. The game is used to train, develop creative thinking, improve communication skills when teaching students Russian as a foreign language.

\section{References}

1. I. Buil, S. Catalán, E. Martínez, The International Journal of Management Education, 17(2), 162-171 (2019) https://doi.org/10.1016/j.ijme.2019.02.002

2. I. A. Ștefan, J. B. Hauge, F. Hasse, A. Ștefan, Procedia Computer Science, 162, 745753 (2019) https://doi.org/10.1016/j.procs.2019.12.046

3. L.Vos, The International Journal of Management Education, 13(1), 57-74 (2015) https://doi.org/10.1016/j.ijme.2015.01.001

4. Y. Chaudy, T. Connolly, Entertainment Computing, 30, 100294 (2019) https://doi.org/10.1016/j.entcom.2019.100294

5. H.T. Hung, J. C. Yang, G.-J. Hwang, et al., Computers \& Education, 126, 89-104 (2018) https://doi.org/10.1016/j.compedu.2018.07.001

6. Y. G. Butler, System, 54, 91-102 (2015) https://doi.org/10.1016/j.system.2014.10.010

7. C. G. Thompson, S. Gillern, Educational Research Review, 30, 100332 (2020) https://doi.org/10.1016/j.edurev.2020.100332

8. Y. L. Tsai, Ch.-Ch. Tsai, Computers \& Education, 125, 345-357 (2018) https://doi.org/10.1016/j.compedu.2018.06.020

9. J. Shishkovskaya, E. Sokolova, A. Chernaya, Procedia - Social and Behavioral Sciences, 206, 232-235 (2015) https://doi.org/10.1016/j.sbspro.2015.10.014

10. P. Bawa, S. L. Watson, W. Watson, Computers \& Education, 123, 174-194 (2018) https://doi.org/10.1016/j.compedu.2018.05.004

11. E. I. Polyakova, Procedia -Social and Behavioral Sciences, 236, 289-294 (2016) https://doi.org/10.1016/j.sbspro.2016.12.031

12. L. Wang, D. Kokotsaki, Thinking Skills and Creativity, 115-130 (2018) https://doi.org/10.1016/j.tsc.2018.06.002 
13. V. Kartashova, Procedia - Social and Behavioral Sciences, 214, 614-618 (2015) https://doi.org/10.1016/j.sbspro.2015.11.767

14. B. F. Klimova, Procedia - Social and Behavioral Sciences, 191, 1157-1160 (2015) https://doi.org/10.1016/j.sbspro.2015.04.312

15. O. Bonerge, P. Lezama, E. N. Manotas, N. Mercado-Caruzo, Procedia Computer Science, 175, 641-646 (2020) https://doi.org/10.1016/j.procs.2020.07.093

16. A. B. Hernández-Lara, A. Perera-Lluna, E. Serradell-López, Computers in Human Behavior, 92, 600-612 (2019) https://doi.org/10.1016/j.chb.2018.03.001

17. B. Mostefai, A. Balla, P. Trigano, Cognitive Systems Research, 56, 82-106 (2019) https://doi.org/10.1016/j.cogsys.2019.03.006

18. P. Bitrián, I. Buil, S. Catalán, The International Journal of Management Education, 18 (1), 100365 (2020) https://doi.org/10.1016/j.ijme.2020.100365

19. Y. Khrushchev, N. Batseva, N. Fix, I. Chesnokova, V. Khar'kovskaya, Procedia Social and Behavioral Sciences, 206, 267-271 (2015 https://doi.org/10.1016/j.sbspro.2015.10.023

20. B. Meskhi, Y. Bulygin, E. Shchekina, V. Maslensky, IOP Conf. Ser.: Earth Environ. Sci. 403, 012089 (2019) doi: 10.1088/1755-1315/403/1/012089

21. I. Kondratieva, T. Rogacheva, N. Malina, E. Vyshegorodskaya, E3S Web of Conferences, 175, 84-96 (2020) doi:10.1051/e3sconf/20201751501

22. E. Vyshegorodskaya, N. Malina, T. Rogacheva, I. Kondratieva, E3S Web of Conferences, $\quad 210, \quad 18014$ https://doi.org/10.1051/e3sconf/202021018014

(2020), ITSE-2020 